\title{
China in the Pacific islands: What are the lessons for Africa?
}

\author{
By Hilary Patroba* \\ Department of Economics, University of Cape Town
}

\section{Introduction}

Pacific Island Countries' (PICs) relation with its partners is based on shared history, common values, economic and trade relations. Over the years, developments on both the Islands and its partners have necessitated renewal of such partnerships and establishment of partnership strategies. The Islands continue to experience a number of challenges in terms of vulnerability, poverty and weak governance. More often than not, the PICs are overlooked in social, economic and development initiatives as their population accounts for a fraction of the world's population. The majority of PICs' population are in Papua New Guinea (PNG).

Every major international actor has an agreement ${ }^{1}$ with the Islands that provides the basis of their relations. The Islands are characterized by substantial natural resources (fish, timber, agricultural products, oil and minerals) whilst climate change effects related challenges. On one hand,

\footnotetext{
* The author is a PhD (Economics) candidate at the University of Cape Town. He has a Master's Degree in Economics from the University of Nairobi. His research interests include trade and development, finance and investment, environment, monetary and health economics and related issues.
} 


\section{AFRICAN \\ EAST-ASIAN \\ AFFAIRS \\ THE CHINA MONITOR}

many international actors are increasing their presence in the region while at the same time, their involvement and influence in the region are declining. On the other hand, new actors are increasingly taking the opportunity to establish a presence in the region.

In these changing circumstances, there is need to analyse the effectiveness of increasing partnerships with the Islands to better understand which actors offer better opportunities to achieving the Islands' social and economic goals as well as mitigating and or addressing the many challenges the region faces and what shared lessons Africa can learn from such engagement. Given that some of the actors also have a presence in Africa, a study on PICs should offer Africa some lessons. This paper seeks to highlight the changing landscape of the PICs, which cooperation approaches are used by actors in the region, what lessons Africa can learn from actors, particularly China's presence in the Pacific Island and to make recommendations on how the actors can optimize their involvement in the region and Africa given their varying comparative advantages.

Below we present the state of Pacific Islands', international actors in the Pacific region, major trading and aid patterns, approaches to cooperation and lessons which African counties can learn from these engagements.

\section{State of Pacific Island; challenges and opportunities}

The Pacific islands experience a number of challenges including poverty (Asian Development Bank 2000b; UN Economic and Social Commission for Asia and the Pacific - UN-ESCAP; 2004; Good; 2003); nevertheless, they have high per capita incomes by developing countries standards and migration from smaller Islands to larger Islands and from 
rural to urban areas (Connell; 2003, World Bank; 2000) due to a high population growth rate. The Islands are also characterized by mixed economic growth with many Islands not achieving their growth potentials (McKenzie et al 2006; Stewart 2008; ABC Radio Australia 2009) and weak political systems coupled with poor governance and civil conflicts (UN-ESCAP; 2004) ${ }^{2}$. Inadequate drinking water and low sanitary levels (UNESCO; 2010, World Health Organization; 2008), food insecurity due to increasing population growth and low nutrition levels due to declining subsistence farming are other challenges facing the region. There are also issues of climate change related disasters such as drought, flooding and catastrophic storms.

Agricultural land in Pacific Island countries such as Fiji, Solomon Islands, Samoa, PNG, Tonga and Vanuatu is fertile and ideal for growing tropical fruits, vegetables and root crops. These countries are, however, constrained with the shortage of usable land as land for commercial agriculture is limited. Larger Islands engage in commercial crop and livestock production at the expense of local food production and as such, many urban populations in the Pacific Islands are dependent on imported foreign food (UN Food and Agriculture Organization; 2008). Pacific Islands' forests have served as sources for food, income, medicine, fuel and building materials. Increasing population and the impacts of human activity such as logging and forest clearance threaten wild harvests, and destroy sources of traditional medicine. National forestry agencies lack capacity to manage forests.

The loss of terrestrial biodiversity is particularly high in the Polynesian and Micronesian Islands. Melanesian islands have the greatest reserve of unaltered terrestrial biodiversity in the sub-region. However throughout 


\section{AFRICAN \\ EAST-ASIAN \\ AFFAIRS \\ THE CHINA MONITOR}

the region, commercial logging, rising populations and the advent of modern agricultural practices imply that the habitats for many plants and animals are being destroyed in favour of cash cropping, construction or other activities (Ministerial Conference on Environment and Development in Asia and the Pacific; 2000). Marine biodiversity is threatened near urban areas by pollution, dredging and filling of coastal habitats, by over- fishing and by destructive fishing techniques such as use of poisons to fish, and excessive use of gill nets. Equally, barriers of reefs surround many of the Pacific Islands while some countries consist entirely of reefs in the form of atolls (Secretariat of the Pacific Regional Environment Program; 2009).

In sum, the PICs face many challenges. However, a major benefit of investing in the Pacific Islands is the attractive lifestyle. The warm tropical climates and the friendly personalities of the great majority of Pacific Islanders are other incentives to invest in the region. While not all types of manufacturing and service industries are suited to the environmental and business conditions of the Pacific Islands, there are numerous opportunities in other industries. Pacific Islands' relative isolation means that passenger, freight connections and boats are important for each country's development. The availability and affordable costs of such services offers alternative opportunities for investments. Box 1 summarises the Islands' constraints and opportunities. 


\section{Box 1. Pacific Islands' constraints and opportunities.}

\section{Constraints to economic development}

- Small domestic market in most of the countries;

- Inadequate infrastructure for many sophisticated, export-orientated projects (the underdeveloped physical infrastructure in several countries is compounded by a relatively weak industrial support base);

- Limited technical skills and/or experience in the workforce;

- High costs of basic utilities (such as power and water) and telecommunications;

- Isolation of the Pacific Islands from the world markets; and in some countries, relatively low productivity levels amongst the workers.

\section{Opportunities for investments}

- The considerable agricultural, timber and mineral resources of several countries have not yet been efficiently developed, and in almost every country there is scope to expand the fisheries sector and to develop viable aquaculture projects;

- The region's fisheries (the region's most significant renewable resource see Figure 1) and the fishing sector that contribute approximately 10 per cent to the countries gross domestic produce offers opportunity for fish processing;

- While most of the local markets are small, there are numerous opportunities for import-replacement projects that can also develop exports to the other Pacific Island markets; 


\section{AFRICAN \\ EAST-ASIAN \\ AFFAIRS \\ THE CHINA MONTTOR}

Issue 2

- Tourism potential in the Pacific Islands is enormous and every government is keen to assist new ventures in this area; and

- The welcoming and increasingly deregulated markets in the islands offer a range of opportunities in the ICT and services sectors.

Source: Author's compilation

\section{Figure 1: Fishery production trends}

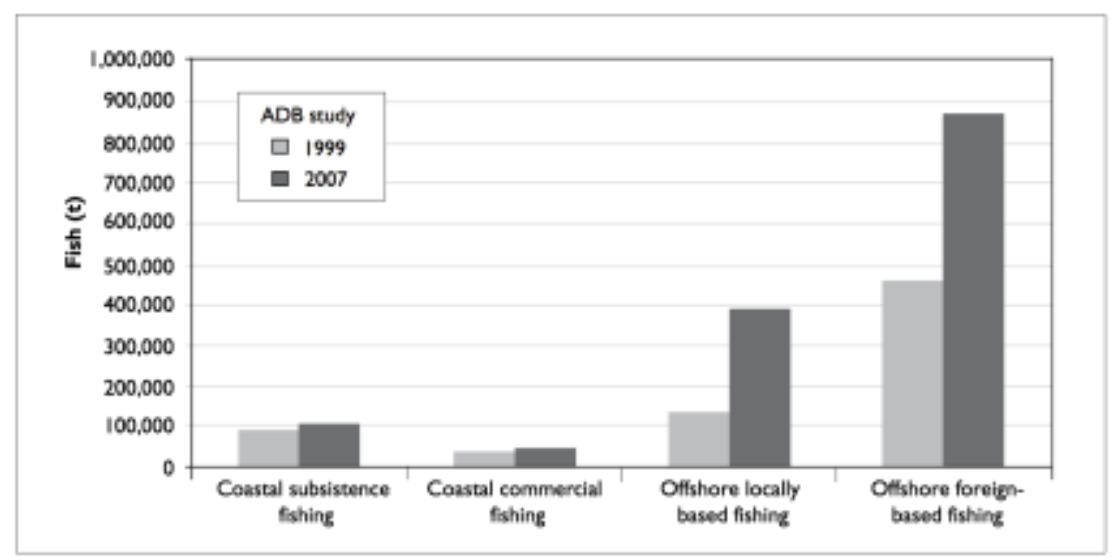

Source: Gillett and Cartwright; 2010: 5.

\section{Traditional donors ${ }^{3}$ and China in the Pacific}

China is now considered to be the third largest aid donor to the PICs, after Australia and the US (Marles MP; 2011, Islands Business; 2011, Pacific Island Forum; 2009), with the majority of its increase in development assistance occurring over the past decade pledging 600 million US dollars between 2005 and 2009. Initially China's motives were part of its rivalry with Taiwan over diplomatic recognition ${ }^{4}$ and 
support for diplomatic objectives. Beijing and Taipei courted Pacific Island states in a bidding war using economic assistance as leverage for support on international issues.

Traditional countries active in the PICs are Australia ${ }^{5}$, New Zealand, the United States and Japan are concerned that "dollar diplomacy", involving unregulated and unconditional foreign aid would add to the underlying economic, social and political issues in the region. By moving into the Pacific Islands, China is challenging not only Taiwan but also the US, Australia, New Zealand and Japan as the prime movers in the region. Unlike China, which is heavily involved in the Pacific Islands, other emerging players - Brazil, Russia, India and Turkey and South Korea to some extent have not ventured in the region to provide aid or invest in the region. However Malaysia and Singapore on other hand are involved in the region through South-South cooperation (SSC).

The EU's relations with the PICs have been structured on the basis of first, the Lome conventions and currently the Cotonou Agreements. Relations with the Pacific Islands have been rocky (Melissa, J \& Melissa, D ;2011, Pacific Institute of Public Policy; 2009, Primack; 2007/08, Trade Negotiation Insight; 2007, Franziska; 2007) in particular with the Economic Partnership Agreements (EPAs) with disagreements arising on whether signing EPAs should be tied to the European Development Fund (EDF) channelled to the PICs and disunity (Pacific Islands Forum Secretariat - PIFS; 2011b) ${ }^{7}$ among the Islanders. EU's political dialogue with individual PICs is limited, however at the regional level, a broad political dialogue is undertaken through a Post Forum Dialogue. Equally, the relations are based on a colonial past with United Kingdom, France and Portugal who are states with greater 


\begin{tabular}{c} 
AFRICAN \\
EAST-ASIAN \\
AFFAIRS \\
\hline THE CHINAMONITOR \\
\hline
\end{tabular}

influence in the region. The EU has an Association Agreement with four Overseas Countries and Territories (OCTs) in the region that is subject to different preference regimes from other African, Caribbean and Pacific countries.

\section{Major trading and aid patterns}

\section{Trade}

Among the PICs, the major trading partners between 2001 and 2005 were the EU and Australia (see Figure 2). However, while the EU reported increased trade volumes from 2006, peaking in 2008 at 4,586,677 thousand US dollars, Australia reported a decline in trade with the PICs in 2004/05. Other trading partners; China, Japan, New Zealand and the United States, have reported a steady trade pattern with the PICs from 2001 to 2008. Over the global economic crisis in 2008/09, Australia, the EU, New Zealand and US reported declining trade volumes. China and Japan, however, recorded increased trade over the period 2008-2010. A comparison of Pacific nations' trade values indicated that China was the main trading partner as its total trade steadily increased from 2001.

All Pacific Island countries are beneficiaries of trade preference programmes offered by major industrialized trading countries and blocs (see Box 2). The EU's new accord with ACP countries, EPAs under the Cotonou Agreement, offers additional trade preferences to PNG and Fiji ${ }^{9}$. Australia and New Zealand offer preferential treatment to imports from PICs pursuant to the South Pacific Regional Trade and Economic Cooperation Agreement (SPARTECA). In 2001, the sixteen members of the Pacific Islands Forum ${ }^{10}$ signed the Pacific Agreement on Closer Economic Relations (PACER), which aims to facilitate the establishment 
of free trade agreements, first among the Islands and then between the Islands and Australia and New Zealand. Currently, PACER plus negotiations are ongoing.

\section{Figure 2: Total Trade of selected $\mathrm{PICs}^{8}$ in thousand US\$ (2001 - 2010)}

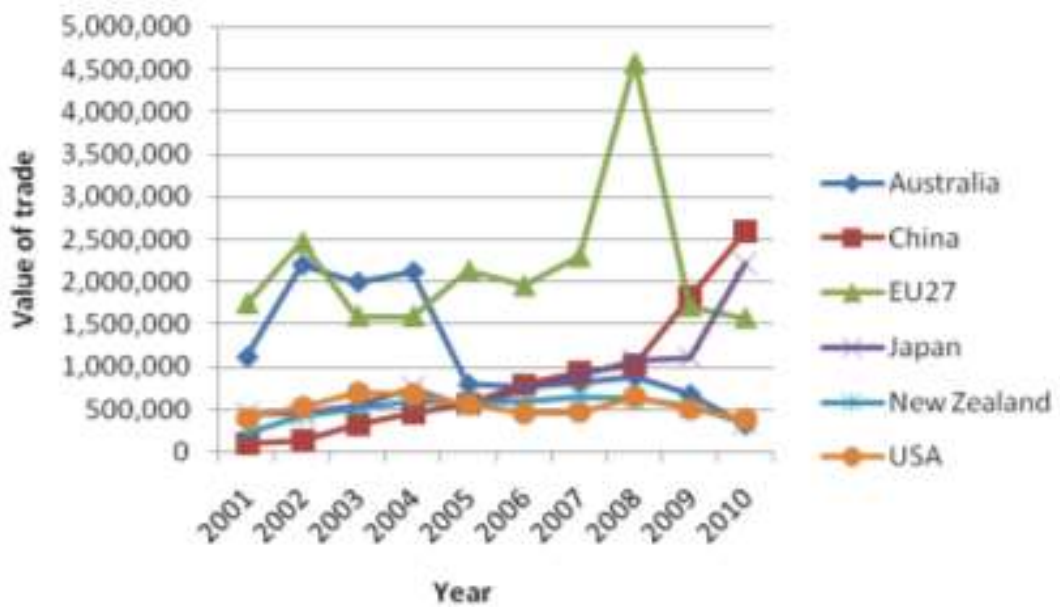

Source: International Trade Centre, http://www.trademap.org/ Bilateral TS.aspx

PACER plus ${ }^{11}$ was triggered by the fact that the Pacific Islands initiated EPAs with the EU. Progress has been made on the PACER plus with Australia and New Zealand committing to fund operations of the Office of the Chief Trade Advisor (OCTA) charged with its smooth negotiations. They have also undertaken to address labour mobility issues raised by the Forum Island Countries (FICs) at the latest negotiations (PIFS; 2011a, Robert; 2010). The focus of the current 


\section{AFRICAN \\ EAST-ASIAN \\ AFFAIRS \\ THE CHINA MONITOR}

negotiation will shift to customs procedures, rules of origin and development assistance related issues at a Forum leaders meeting in September 2011.

On Pacific Island Countries Trade Agreement (PICTA), there is progress made on negotiations to strengthen, expand and diversify trade between the FICs for the elimination of tariffs and non-tariff barriers in the region (Pacific Island Forum; 2011). Both Pacific region EPAs and Pacific Agreement on Closer Economic Relations (PACER) ${ }^{12}$ negotiations are still ongoing with various challenges. Australia's regional interests focus on the Islands south of the equator, including the relatively large Melanesian nations of PNG and the Solomon Islands as well as Vanuatu. New Zealand has long-standing ties with the territory of Tokelau, the Cook Islands and Niue. Although China has been courting the Pacific nations, they are yet to sign any trade pact as are other actors in the islands.

\section{Box 2: Pacific Island countries preferential trade access}

The Pacific Island economies have preferential access to many overseas markets.

- Duty-free access to the Australian and New Zealand markets is allowed for products with a Pacific Island and/or Australian/New Zealand content of at least $50 \%$.

- The Generalised System of Preferences (GSP) provides concessional entry for some of Pacific Island products into the United States, Canada, Japan and EU

- Interim Economic Partnership Agreements (Kennan \& Meyn; 2009, Bilan \& Ramdoo; 2010) ${ }^{13}$ (IEPAs) as a preferential rule of origin for export of processed fish and marine products to the European markets. 
- The Melanesian Spearhead Group Agreement (MSG) allows duty free or preferential access for a range of products produced in and exported between the Fiji Islands, PNG, the Solomon Islands and Vanuatu (while the Fiji Islands also has similar bilateral trade agreements with several countries in the region).

Source: Author's compilation

\section{Foreign Aid}

The Pacific Island region has among the highest rates of foreign aid per capita in the world. This is due to their low population levels compared to the other countries. The largest donors in terms of official development assistance (ODA) are Australia, the United States, and Japan. Other large providers are New Zealand and EU institutions (see Figure 3). The bulk of US funding in the region goes to the Freely Associated States. Australian aid is directed primarily to Melanesian and Polynesian states, while New Zealand aid flows mostly to Polynesia (Asian Development Bank 2000a). However the situation has changed over the years with EU institutions, France, and Japan reportedly having increased their development assistance in the region, while Australia and New Zealand have added conditions on aid such as good governance and integrity and the United States and the United Kingdom have cut back on their programs.

This new situation has given China an opportunity to increase its aid to the region with varying opinion that China has become the third largest provider of foreign assistance in the region (Islands Business; 2011, Islands Business; 2009, Foreign Affairs; 2006, Squires; 2005). As Samoan Prime Minister recently pointed out, "The uniqueness of the Chinese assistance is its flexibility and very quick response by the authorities in China" (Malielegaoi; 2012). China's aid to the Pacific 


\begin{tabular}{|} 
AFRICAN \\
EAST-ASIAN \\
AFFAIRS \\
\hline THE CHINA MONITOR \\
\hline
\end{tabular}

Islands is in the form of soft loans and infrastructure projects (see Figure 4 and 5).

\section{Figure 3: Total net Official Development Assistance (US\$ millions)}

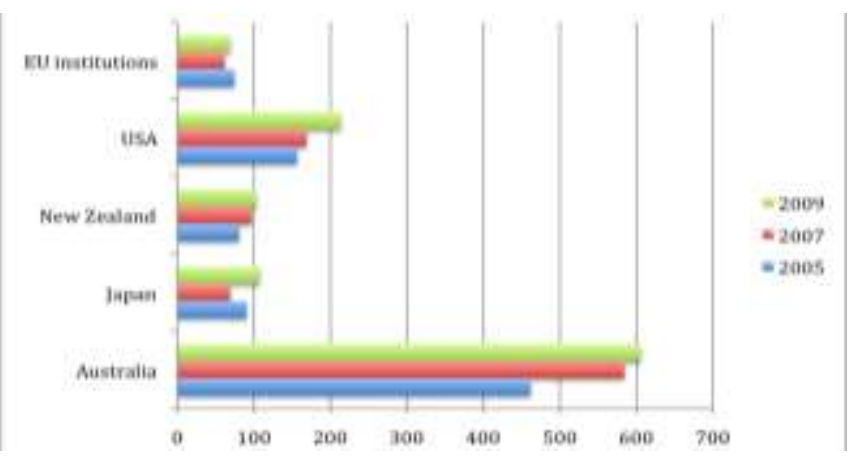

Source: Organization for Economic Cooperation and Development (OECD), http://stats.oecd.org/

Figure 4: China's aid by grants and loans (2008 and 2009, US\$ millions)

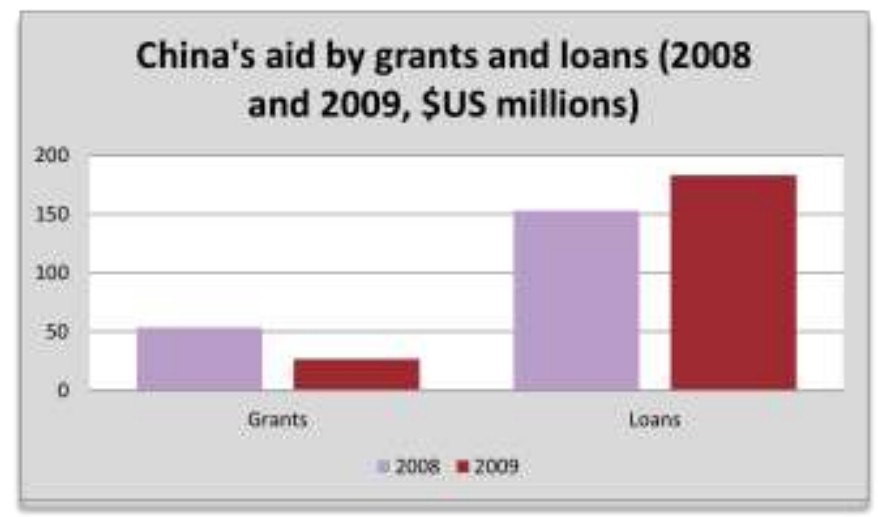

Source: Fifita \& Hanson 2011, p. 6. 


\section{Figure 5: Cumulative Chinese aid loans as a percentage of GDP (2005-2009)}

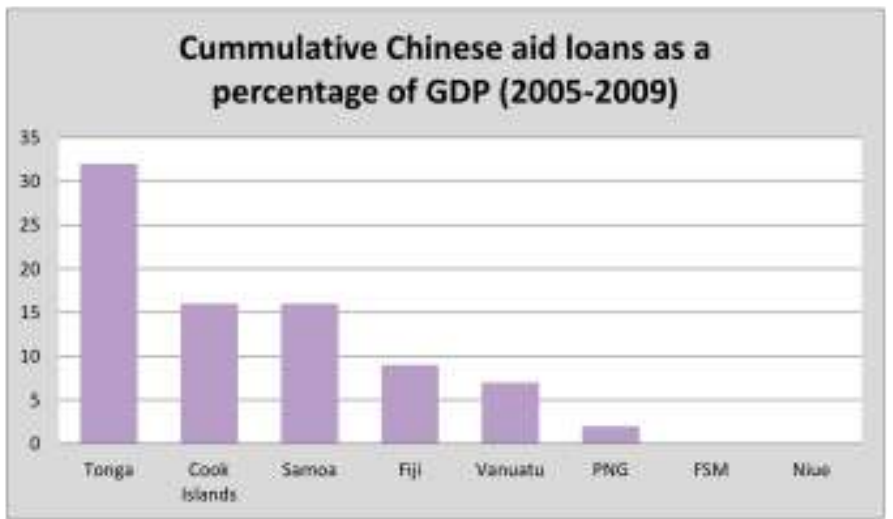

Source: Fifita \& Hanson; 2011: 6.

\section{Approaches to cooperation with the Pacific}

While Pacific Islands' partners aid programs offer insight into their aid policies, they differ in approach and objective. The Cairns Compact on Strengthening Development Cooperation in the Pacific (PIFS; 2009) for example aims to coordinate donor assistance to the Pacific Islands countries. This is part of the Pacific strategy promoted by the Asian Development bank, the World Bank, AusAID and the New Zealand Agency for international development. This strategy's key objective is to enhance more effective coordination of available development resources in the pacific.

Emerging players on the other hand subscribe to SSC and triangular development cooperation (TDC) for development experience sharing with China and India spending approximately 0.7 percent of their 


\section{AFRICAN \\ EAST-ASIAN AFFAIRS}

national income on SSC related activities (see Table 1 for a summary of SSC activities of selected Asia-Pacific developing countries). Some Pacific Islands' are setting up sovereign wealth funds (Wrights; 2011) as a new approach to tapping their potentials (eg. PNG). More recently, China, New Zealand and the Cook Island have partnered to improve water, health and sanitation services in the islands (Xinhua; 2012). Other opportunities that could arise from SSC include:

- Enhanced agricultural research and development to achieve food security

- Improved coordination in medical services provision

- Facilitating improved information communication technologies (ICT) connectivity

- Better disaster mitigation and

- More responsive global economic governance. 
Table 1: Summary of SSC activities of selected Asia-Pacific developing countries

\begin{tabular}{|c|c|c|c|c|}
\hline 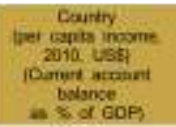 & $\begin{array}{l}\text { Fuimaded: } \\
\text { Scake USt } \\
\text { ndibin } \\
\text { is of gno } \\
\text { 2010 }\end{array}$ & $\begin{array}{l}\text { Fichert } \\
\text { courants }\end{array}$ & 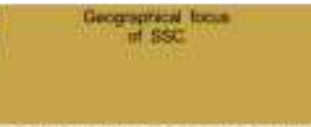 & Score of Ssec \\
\hline $\begin{array}{l}\text { Cine } \\
\text { 4. } 3893 \\
(5.21)\end{array}$ & $\begin{array}{l}3 \mathrm{Nar} \\
\text { past }\end{array}$ & $16 t$ & 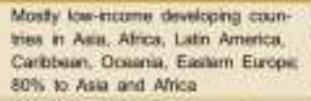 & 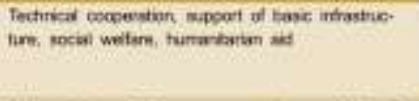 \\
\hline $\begin{array}{l}\text { Indir } \\
\text { 11 } 2659) \\
(3,19)\end{array}$ & $\begin{array}{l}705-1,000 \\
0004-0.07)\end{array}$ & 358 & 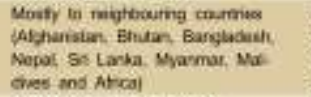 & 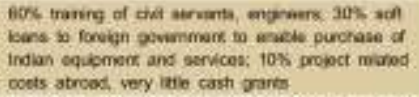 \\
\hline 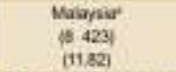 & 164. & 40 & Atrica, Asea Pacifo istands & 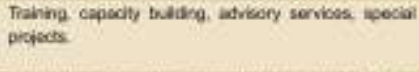 \\
\hline 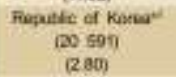 & $\begin{array}{l}1168 ? \\
10.12\end{array}$ & 127 & 405, Aele ton Anca & 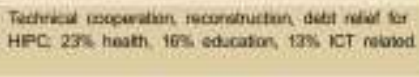 \\
\hline 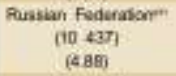 & $400-500$ & + & $\begin{array}{l}\text { ClB courtive ESCAP Coutrias, } \\
\text { Atrou }\end{array}$ & 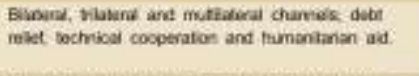 \\
\hline $\begin{array}{l}\text { Sngwoon } \\
(43117) \\
(2221)\end{array}$ & - & 160 & 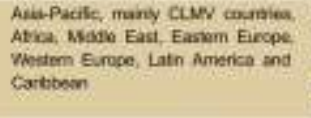 & 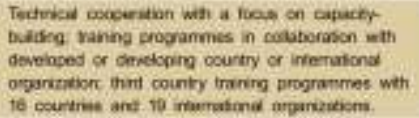 \\
\hline $\begin{array}{l}\text { Thelond } \\
\text { (4 992) } \\
(484)\end{array}$ & $\infty 0 .+11$ & + & Marby CLMV ocurtiles:- & 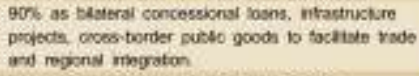 \\
\hline $\begin{array}{l}\text { Tuney } \\
(70399) \\
(-6=5)\end{array}$ & $\begin{array}{l}907 \\
0030\end{array}$ & $13 t$ & LOOs, Atngs, Ads & Eocnomio and soded ntastructive popeds. \\
\hline
\end{tabular}

Source: UN Economic and Social Commission for Asia and the Pacific ESCAP, 2011, p. 3.

\section{Bottlenecks in Chinese engagement in the Pacific; correlation to African problems?}

China is well known in its generosity to issue concessional loans in its engagement in the Pacific. Nevertheless, these loans, to some extent, have lead to national indebtedness of the Pacific Islands resulting to huge debt burden to future generation as witnessed in Tonga. This fear has made PNG, for instance, to control the amount of loans it receives from China (Smith; 2012b). Other key issues of concern to Pacific 


\section{AFRICAN \\ EAST-ASIAN \\ AFFAIRS \\ THE CHINA MONTTOR}

Islands are;

\section{Contractor-driven $O D A$}

The PICs argue that although majority of Chinese contractors are State funded entities, there is always the likelihood of eventually firms subcontracting tenders awarded to them for specialized areas such as electrification. The Island nations such as PNG, has only signed contracts with state funded firms and not the Chinese government that funds the projects. This, the PICs suggests, could lead to irresolvable contractual issues (Smith; 2012b), particularly when the funds are frozen due to unforeseen misunderstanding between the contracted firms and their funders, the Chinese government. In sum, "Chinese 'aid' is often a bottom-up rather than a top-down process" (Smith; 2012a). Equally, to enhance partnerships with the Pacific, China has endeavoured to cooperate with the Islands, particularly by supporting the regional cooperation programs of the Pacific Island Forum Secretariat. Royalties to property owners are always required to be paid up by the contracted firms.

This, a time turns out to be a challenge that Island nations face when dealing with the Chinese contractors. Subcontracting of contracts to, for instance, a subsidiary that specialises on a particular field has resulted in most cases to complications on which firm - contracted or subcontracted ones, ought to pay such royalties (Smith; 2012b). In Africa, although Angola recently signed a US\$500 million agreement with China's Exim bank to finance various reconstruction projects (CSC; 2012d), these projects will most likely be done my Chinese contractors and subcontractor. Elsewhere in Uganda, the construction of a US\$350 
million Chinese funded road (connecting the Uganda international airport and the Capital), the agreement stipulates that it must be done by Chinese contractors raising questions on competitiveness in tendering process for a contractor (CSC; 2012f). These among other examples in Africa raise similarities in Pacific and Africa's challenges when engaging the Chinese on construction projects.

\section{Labour issues}

Labour and employment related issues are another key challenge facing the Pacific-China relations. Although Chinese contractors are praised for being adoptive to local conditions as compared to local or traditional contractors, Chinese companies mainly employ Chinese nationals and to a small extent, local in conducting their operations. This has raised lots of complains among the PICs on how the local governments to handle immigration issues when Chinese nationals are employed (Smith; 2012b: 8, Hank; 2010, The Australian; 2007). An argument put forward to defend the practice by Chinese companies is that raw materials and shipment of Chinese workers minimizes their operation costs. Across Africa, Chinese construction companies have been accused of similar concerns.

They have widely been accused of employment malpractices including; poor remuneration of African employees, employment of Chinese prisoners as cheap labour, among others in countries such as Angola where recently, 37 illegal Chinese immigrants were arrested and deported (CSC; 2012a); Kenyan businessmen also recently demonstrated against Chinese hawkers in some parts of the country claiming that the Chinese are taking up their businesses; (The Star; 2012) Sudan and 


\begin{tabular}{c} 
AFRICAN \\
EAST-ASIAN \\
AFFAIRS \\
\hline THE CHINAMONITOR \\
\hline
\end{tabular}

Zambia sought help from China to help resolve their unemployment levels by encouraging Chinese firms to Invest in the country (CSC; 2012e) as well as helping train African in business courses under the umbrella of China-Africa business cooperation (CSC; 2012b); In Ghana, illegal Chinese miners were purported to having invaded an Anglogold Ashanti concession (CSC; 2012c) and arrested to answer to charges. These events highlight commonality in challenges faced by Pacific and Africa in their partnership with China.

\section{Crime}

In addition, Pacific Islands are perceived to be the hub for Asian crimes such as the drug trade, human trafficking, smuggling, money laundering, prostitution, illegal gambling, fraud and theft, with the Chinese being the main perpetrators (Smith; 2012b). For instance, Chinese traffickers are believed to have corrupted PNG's police forces to facilitate their illegal activities. As such, China's engagement with the Pacific Islands is seen to help combat these vices (Powles; 2010). Making opening remarks at the $43^{\text {rd }}$ Pacific Islands Forum, the Secretary General of the Secretariat noted that:

'Transnational crime continues to be a human and economic security threat, and remains a matter of concern and priority for law enforcement agencies of the region. Recent statistics indicate that the region is being actively targeted as a transit route for the trafficking of arms, people and illicit drugs. We commend the efficient and coordinated efforts by national and regional law enforcement agencies to combat these criminal activities and threat' (Tuiloma; 2012: p. 2 of 3). 
In Africa, China is mainly accused of criminal related activities such as the proliferation of counterfeit goods across many African cities (Patroba; 2012) and poaching of wild animals such as elephants and rhinos. Overall, Africa seems to be facing the same challenges in their engagement with the Chinese as is the Pacific Islands. To this end, given that China has been embracing accusations against its involvement in the Pacific, this has led to some positive responses from China which have been reported in the islands. The continued pressing of China to improve its image in the region for mutual future engagement has played a huge role in this regard. As such the two regions can learn from each other and share experiences in their engagement with Beijing. In the next section we postulate some lessons Africa can learn from China-Pacific relations.

\section{Lessons for Africa}

Lessons to be drawn cannot be understood as blueprint options from the Pacific region; Africa is a continent with a specific outlook and history. Its domestic sectoral policies, provincial governments and private actors highlight various African countries internal intricacies. As China's presence in the continent increases, key issues Africa should consider while engaging with the former are: Sound implementation of existing frameworks; effectively using support extended to them through sound governance mechanisms; prudent complementarities, coherence and coordination of regional and national interests and cultivating a culture of inclusiveness in engagement with China through a private-public sector partnership such as the China-South African Development Community business forum. These are issues that the Pacific Islands have dealt with in their engagement with China, realising remarkable 


\begin{tabular}{|} 
AFRICAN \\
EAST-ASIAN \\
AFFAIRS \\
\hline THE CHINA MONITOR
\end{tabular}

levels of success. More importantly, Africa could press China to improve its operations in the continent particularly on issues concerning contractors and subcontractors, labour issues and crime in the continent attributed to Chinese involvement. To achieve this, Africa could share best practices from the Pacific Islands such as raising complains with the Chinese each time there is a grievance. This, for instance, is an area the Islands have effectively used to draw Chinese attention. Other lessons Africa could learn from the Islands are on issuing situational conditions to Chinese contractor and subcontractors in a similar fashion as PNG freezing of Chinese loans and the Cook Island which have temporarily put on hold USD\$ 37 million loan from the Chinese (Smith; 2012b) to optimize Chinese engagement.

Comparatively, Pacific Islands are endowed with different resources to Africa, particularly the latter's abundance of minerals. As such, China engages with the two regions separately, to some extent. Nevertheless, lessons that Africa can learn from Chinese involvement in the Pacific Islands are: First, Africa must continue to press China on issues of technological transfer including Information Communication Technology, as practiced in the Islands where PICs nationals are offered training by Chinese technology firms to advance their skills thus transferring knowledge. Whereas Chinese contracts in Africa are majorly done by Chinese nationals, there is need for technological transfers through incorporating Africans in development and infrastructural projects undertaken by the Chinese. This, it is believed, would enable African contractors to competitively compete with the Chinese in the tendering process and provision of technical services during such contracts. Interestingly, technological transfer by the Chinese to the islands has tremendously benefited the PICs towards modernizing 
indigenous people's skills and companies' expertise towards international standards. Africa, to this end, could learn from the islands in their engagement with the Chinese.

Second, Africa should press Chinese companies, a practice that have been perfected by the PICs, to uphold standards of corporate social responsibility and crime prevention (for example, PNG collaborates with the Chinese authorities in combating crime) to encompass issues such as disaster mitigation through prosecution of Chinese law breakers in the continent as the Pacific Islands have done and the provision of medical services to local communities where Chinese companies are involved (this can be done by allowing and encouraging locals to use medical facilities used by Chinese employees). Similarly, Africa ought to press China to address labour and employment issues raised during their involvement in Africa. As is common knowledge, African citizens, as the PICs are, care more about social dimensions of economic development in their regions since they know that the consequences of environmental degradations during any project implementation are costly.

Finally, African countries should involve all stakeholders including the private sector, civil society, research and academic institutions in their engagement with China in order to enhance African ownership of projects undertaken by Chinese companies to promote research and development for instance agricultural production to enhance food security in Africa. These are motivated by the fact that, as highlighted beforehand, PICs and Africa shares lots of similar challenges and opportunities in their engagement with the Chinese. 


\section{AFRICAN \\ EAST-ASIAN \\ AFFAIRS \\ THE CHINA MONITOR}

\section{Conclusion}

The place of Pacific Islands' relation with old partners is increasingly under challenge. With Brazil partnering with the African Development Bank (AfDB) to set a fund (AfDB; 2011 \& South-South Cooperation Trust Fund; 2011) channeled for SSC, it remains to be seen if such partnership will extend to Pacific Islands through the Asian Development Bank given AfDB has expressed interest to include Inter-American Development Bank in the agreement (Thierry; 2011). Indeed, followed swiftly by China (AfDBb; 2011), other emerging players will most likely follow thus greater SSC and TDC visibility (UN -ESCAP; 2011). Already, China, New Zealand and Cook Island have formed a TDC to improve water, health and sanitation services in the island (Xinhua 2012). Although Pacific Islands have been marginalized for a long time, it could be that in the Asian century, more investment would flow to the Islands.

For Africa, it is clear that they are grabbing the opportunity brought by China as the latter is involved in massive infrastructural investments and development projects (Bilal \& Rampa; 2011) ${ }^{14}$ and as the traditional partners reform their development policies (eg. Australia ${ }^{15}$ and New Zealand in the Pacific Islands) and China design their policies in the Pacific Island, African countries could learn from China's involvement in the Pacific, particularly at this time that the continent considers its future after 2020 - the expiry of the Cotonou agreement and other bilateral agreements such as African Growth and Opportunity Act (AGOA), SSC could opens a new avenue for new cooperation with China. Additionally, Africa can endeavour to leverage on China's 
ambition to become a world's power house by pushing the attainment of mutually agreed modes of engagement towards a addressing challenges wishing China-Africa relations.

\section{End Notes}

1 For example, under the revised Cotonou Agreement and the European Consensus with the EU and the Paris Declaration on Aid effectiveness adopted in march 2005 that outlines the commitments to harmonize and align aid policy with set targets with the region among other agreements/ strategies with Australia, New Zealand, USA and Japan.

${ }^{2}$ For example, the political and civil insecurity in Fiji, Solomon Islands and PNG have weak economic and social institutions.

3 "Traditional" donors are those that gather in the OECD Development Assistance Committee (DAC).

${ }^{4}$ The Republic of the Marshall Islands, the Solomon Islands, Palau, Kiribati, Tuvalu and Nauru recognize Taiwan's legitimacy.

${ }^{5}$ In 2003 the Australian Senate Foreign Affairs, Defence and Trade Committee reported on China's emergence as a global power and the implications for Australia. In a chapter on the Southwest Pacific, the committee concluded that Australia should encourage China to "adopt and adhere to" the OECD guidelines on development assistance and that Australia should "work closely with China to encourage both countries to enter joint ventures designed to assist the development of the island states of the SW Pacific".

${ }^{6}$ The use of large amounts of unconditional aid in exchange for support on international issues. 


\section{AFRICAN \\ EAST-ASIAN \\ AFFAIRS \\ THE CHINA MONITOR}

${ }^{7}$ Though there is lack of confidence in the Pacific Island Forum Secretariat to lead the region on EPAs negotiations, modalities are in place to transfer this role to PACER plus' office of the trade advisers.

${ }^{8}$ Fiji, Marshall Islands, French Polynesia, Nauru, Niue, Palau, PNG, Samoa, Solomon Islands, Tonga and Vanuatu. Due to lack of data, Cook Islands, Kabiatu and Tuvalu are not included.

${ }^{9}$ Other PICs are still negotiating EPAs with the EU. For monthly update on Pacific - EU EPAs negotiations see Trade negotiations insight, http://www.acpeu-trade.org/index.php?loc $=$ tni/.

${ }^{10}$ The 14 sovereign PICs plus Australia and New Zealand.

${ }^{11}$ Was launched in August 2009 with an aim to strengthen the Forum Island Countries ability to trade by enhanced trade capacity building and trade development assistance.

${ }^{12}$ A regional trade and economic agreement with Australia that provides long term opportunity to create jobs, enhance private sector growth, raise standards of living, and boost economic growth as well as trade capacity building and trade development assistance in Forum Island Countries.

13 PNG and Fiji has agreed an EIPA with the EU since November 2007, Kiribati, Samoa, Solomon Islands Tuvalu and Vanuatu all least developed countries (LDCs) benefits from everything but arms initiative that offers duty free quoter free access to EU markets while non-LDCs - Cook Islands, Tonga, Marshall Islands, Micronesia, Niue, Palau and Nauru - have not joined the IEPAs have benefited from GSP scheme from January 2008.

${ }^{14}$ For various publications on China in Africa see SAIIA's China in Africa Project; http://www.saiia.org.za/china-in-africa-project/china-in-africa-projectpublications.html and China Monitor published by Centre for Chinese Studies at Stellenbosch University, http://www.ccs.org.za/?cat=6. 
${ }^{15}$ For example Australia's White paper advocates for a more structured and targets performance management to promote mutual responsibility and accountability.

${ }^{16}$ For example PNG alone is estimated to have five times as many fish species than the entire Caribbean.

17 The Polynesian nations include Tonga, Samoa, American Samoa, Cook Islands, Wallis and Futuna, French Polynesia, Pitcairn Islands, Niue, Tokelau, and Tuvalu. Polynesian islands vary from volcanic islands with some fertile land to low-lying coral atolls or phosphate rock islands.

18 Includes the Federated States of Micronesia, Guam, Palau, the Commonwealth of the Northern Mariana Islands, Kiribati, Marshall Islands, and Nauru.

${ }^{19}$ PNG accounting for $84 \%$ of the land area of the entire Pacific Islands region, with the Solomon Islands, Vanuatu, New Caledonia and Fiji forming a further $14 \%$.

\section{References}

ABC Radio Australia. 2009. 'Rudd and Key Announce Pacific Study on Financial Crisis', retrieved on 20 July 2012 from http://www.radioaustralia.net.au/ pacbeat/stories/200903/s2505319.htm.

African Development Bank (AfDBa). 2011. 'South-South Cooperation Trust Fund', retrieved on 20 July 2012 from http://www.afdb.org/en/topics-andsectors/initiatives-partnerships/south-south-cooperation-trust-fund/ and http:// www.afdb.org/en/news-and-events/article/afdb-sets-up-new-trust-fund-withbrazil-7803/.

_. 2011b. AfDB Signs Multi-Million Cooperation Agreements with China and Brazil, retrieved on 20 July 2012 from http://www.afdb.org/en/news-and- 


\section{AFRICAN \\ EAST-ASIAN \\ AFFAIRS \\ THE CHINA MONITOR}

events/article/afdb-signs-multi-million-cooperation-agreements-with-china-andbrazil-8144/

Asian Development Bank. 2000a. 'Regional Technical Assistance for Poverty Assessment in Pacific Developing Member Countries', retrieved on 20 July 2012 from http://www.adb.org/Documents/TARs/REG/tar reg3349801.pdf.

_.2000b. 'A Pacific Strategy for the New Millennium'. Policies and strategies, retrieved on 20 July 2012 fromhttp://www2.adb.org/documents/policies/ pacific strategy/default.asp\#contents.

Bilal, San. and Rampa, Francesco. 2011. 'Emerging economies in Africa and the development effectiveness debate'. ECDPM Discussion Paper 107. Maastricht: European Centre for Development Policy Management, retrieved on 20 July 2012 from www.ecdpm.org/dp107.

Bilan, San. and Ramdoo, Isabelle. 2010. 'Which way forward in EPA negotiations? Seeking political leadership to address bottlenecks', ECDPM Discussion Paper 100. Maastricht: European Centre for Development Policy Management, retrieved on 20 July 2012 from www.ecdpm.org/dp100.

Connell, J. 2003. 'Migration in Pacific Island countries and territories'. (ed) Chapter 11 in Migration Patterns and Policies in the Asian and Pacific Region. UN Economic and Social

Commission for Asia and the Pacific. Asian Population Series No 160, retrieved on 20 July 2012 from http://www.unescap.org/esid/psis/population/ popseries/apss160/apss160chap2.pdf.

Centre for Chinese Studies (CCS). 2012a. 'The Weekly China Briefing', 31th August, retrieved on 04 September 2012 from http://www.ccs.org.za/wpcontent/uploads/2012/08/Weekly-China-Briefing-31-August-2012.pdf.

_. 2012b. 'The Weekly China Briefing', 27th June, retrieved on 30 August

2012 from http://www.ccs.org.za/wp-content/uploads/2012/07/Weekly-China- 
Briefing-27-July-2012.pdf.

_. 2012c. 'The Weekly China Briefing', 22nd June, retrieved on 30 August

2012 from http://www.ccs.org.za/wp-content/uploads/2012/06/Weekly-ChinaBriefing-22-June.pdf.

_. 2012d. 'The Weekly China Briefing', 13th July, retrieved on 30 August 2012 from http://www.ccs.org.za/wp-content/uploads/2012/07/Weekly-ChinaBriefing-13-July-2012.pdf.

_. 2012e. 'The Weekly China Briefing', 8th June, retrieved on 30 August 2012 from http://www.ccs.org.za/wp-content/uploads/2012/06/Weekly-ChinaBriefing-Double-Source-8-June-Dewi.pdf.

_. 2012f. 'The Weekly China Briefing', 04 May, retrieved on 30 August 2012 from http://www.ccs.org.za/wp-content/uploads/2012/05/Weekly-ChinaBriefing-Double-Source-4-May-2012.pdf

Foreign Affairs. 2006. 'Defense and Trade References Committee, Senate of Australia. "China's Emergence: Implications for Australia", Commonwealth of Australia, retrieved on 20 July 2012 from http://www.comw.org/cmp/ fulltext/0603chinareport.pdf.

Franziska, Jerosch. 2007. 'Pacific, EU aid dispute; the link between aid and EPAs', Trade Negotiation Insight, Vol. 6 No. 5, retrieved on 20 July 2012 from http://www.acp-eu-trade.org/index.php?loc=tni/.

Fifita, Mary and Hanson, Fergus. 2011. 'China in the Pacific: The New Banker in Town' Pacific Forum CSIS, Issues and Insights, Vol. 11 - No. 5, retrieved on 20 July 2012 from http://csis.org/files/publication/issuesinsights_v11n05.pdf.

Gillett, I. Robert and Cartwright, Ian. 2010. 'The Future of Pacific Island Fisheries', Secretariat of the Pacific Community, Noumea and the Forum Fish- 


\section{AFRICAN \\ EAST-ASIAN \\ AFFAIRS \\ THE CHINA MONITOR}

eries Agency, Honiara, retrieved on 20 July 2012 from http://www.spc.int/fame/ doc/corporate docs/Future of PI fisheries Report.pdf.

Good, Lydia. 2003. 'Poverty in the Pacific - An Analysis'. Pacific Issues, Paper No 6. Directorate

General for Development, European Commission, retrieved on 20 July 2012 from http://www.ecsiep.org/documents/resource/06 poverty.pdf.

Smith, Graeme. 2012a. 'Are Chinese soft loans always a bad thing?', 29th March, retrieved on 04 September 2012 from http://www.lowyinterpreter.org/ post/2012/03/29/Are-Chinese-soft-loans-always-a-bad-thing.aspx.

. 2012b. 'Beyond the reach of the whip: Chinese Investment in Papau New Guinea', CCS - African East Asia Affairs, The China Monitor, Issue 73, retrieved on 04 September 2012 from http://www.ccs.org.za/wp-content/ uploads/2012/07/China_Monitor_JULY_2012_final.pdf.

Hank, Nelson. 2010. 'China in Papua New Guinea', (ed.) in China in Oceania: Reshaping the Pacific, United States, Bergham Books, retrieved on 03 September 2012 from http://books.google.co.ke/books?

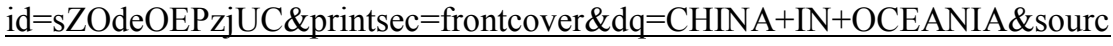
$\mathrm{e}=\mathrm{b} 1 \&$ ots $=\mathrm{z} 2 \mathrm{dk} 4 \mathrm{q} 4 \mathrm{t}-$ $\mathrm{y} \&$ sig $=\mathrm{N} 8$ clM2CFszr0PP2LYLE6kbsKW4\&hl=en\&sa $=$ X\&ei=ZVxEULDeBqP0AXR34HABQ\&redir_esc $=\mathrm{y} \# \mathrm{v}=$ onepage $\& \mathrm{q}=\mathrm{CHINA} \% 20 \mathrm{IN} \%$ 20OCEANIA\& $\mathrm{f}=$ false.

Islands Business. 2011. China's growing footprint no cause for panic, 20th March, retrieved on 20 July 2012 from http://www.islandsbusiness.com/news/ index_dynamic/containerNameToReplace $=$ MiddleMiddle/focusModuleID=130/ focusContentID $=22942 /$ tableName $=$ mediaRelease overideSkinName=newsArticle-full.tpl. 
. 2009. China's Pacific handouts hit $\$ 254 \mathrm{~m} .12^{\text {th }}$ July, retrieved on 20 July 2012 from http://www.islandsbusiness.com/news/index_dynamic/ containerNameToReplace $=$ MiddleMiddle $/$ focusModuleID $=130 /$ focusContentID $=16134 /$ tableName $=$ mediaRelease $/$ overideSkinName=newsArticle-full.tpl.

Kennan, J. C. Stevens and Meyn, M. 2009. 'The CARIFORUM and Pacific ACP Economic Partnership Agreements: Challenges Ahead'. Economic Paper Series, London: Commonwealth Secretariat, retrieved on 20 July 2012 from http://publications.thecommonwealth.org/the-cariforum-and-pacific-acpeconomic- partnership agreements-681-p.aspx.

Malielegaoi, Tuilaepa Sailele. 2012. 'Samoan Prime Minister Interview to Xinhua News ahead of the 43rd Pacific Island Forum (PIF) leaders meeting', retrieved on 04 September 2012 from http://www.chinadaily.com.cn/ world/2012-08/30/content_15719023.htm.

Marles MP, Hon Richard. 2011. 'Australian Parliamentary Secretary for Pacific Island Affairs, Transcript of Interview on Pacific Beat, Radio Australia, Australia's reaction to concerns about China's loans to Pacific countries', $4^{\text {th }}$ April, retrieved on 20 July 2012 from http://ministers.dfat.gov.au/marles/ transcripts/2011/rm tr 110406 radio australia.html.

Melissa, Julian and Melissa, Dalleau. 2011. 'EPA update', Trade Negotiation Insight, Issue 4, Vol. 10, retrieved on 20 July 2012 from http://www.acp-eutrade.org/index.php?loc $=$ tni/.

McKenzie, E. et al. 2006. 'Economic Impact of Natural Disasters on Development in the Pacific'. AusAID Report, retrieved on 20 July 2012 from http:// www.ausaid.gov.au/research/pubout.cfm? $\underline{\mathrm{ID}=9988 \quad 7222 \_3332 \_5331 \_7333 \& \text { FromSection=Publications\&Type=All } .}$

Michael, Powles. 2010. Challenges, Opportunities and Case for Engagement, 


\section{AFRICAN

(ed.) in China in Oceania: Reshaping the Pacific, United States, Bergham Books, retrieved on 03 September 2012 from http://books.google.co.ke/books

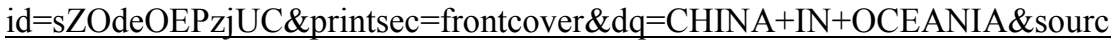

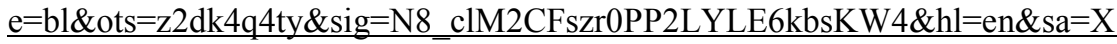
$\underline{\text { eei }=\mathrm{ZVxEULDeB}-\mathrm{qPOAXR} 34 \mathrm{HABQ} \& \text { redir_esc }=\mathrm{y} \# \mathrm{v}=\text { onepage } \& \mathrm{q}=\mathrm{CHINA} \%}$ 20IN\%20OCEANIA\&f=false.

Ministerial Conference on Environment and Development in Asia and the Pacific. 2000. 'Biodiversity Issues in the Pacific Islands', retrieved on 20 July 2012 from http://www.unescap.org/mced2000/pacific/background/biodiv.htm.

Pacific Island Forum. 2011. 'Trade Ministers meeting's press release on PICTA commitment', retrieved on 20 July 2012 from http://www.forumsec.org/pages.cfm/ newsroom/press-statements/2011/trade-ministers-reconfirm-commitment-to-picta.html.

Pacific Islands Forum Secretariat (PIFS). 2011a. 'Outcome of Forum Trade Ministers Meeting', $18^{\text {th }}-19^{\text {th }}$ May, Vava'u, Tonga, retrieved on 20 July 2012 from http://forum.forumsec.org/pages.cfm/newsroom/pressstatements/2011/2011-ftmm-outcomes document.html.

_. 2011b. 'Secretary General urges Pacific ACP States to unify'. Press statement, $3^{\text {rd }}$ February, retrieved on 20 July 2012 from http://www.forumsec.org/ pages.cfm/newsroom/press-statements/2011/secretary-general-urges-pacific-acp -states-to-unify.html

_. 2009a. 'Cairns Compact on Strengthening Development Coordination in the Pacific', retrieved on 20 July 2012 from http://www.forumsec.org.fj/resources/ uploads/attachments/documents/FEMM\%2009\%20Paper\%20on\%20 Cairns $\%$ 20Compact.pdf.

- 2009b. China hands over grant to member states, Media release, $5^{\text {th }}$ November, retrieved on 20 July 2012 from http://www.forumsec.org/pages.cfm/ newsroom/press-statements/2009/china-assists-forum-countries.html. 
Pacific Institute of Public Policy. 2009. 'Pacific lessons from the EPA', Trade Negotiation Insight, Issue 3, Vo. 8, retrieved on 20 July 2012 from http:// www.acp-eu-trade.org/index.php?loc=tni/.

Patroba, Hilary, 2012. 'China in Kenya: Addressing Counterfeit Goods and Construction Sector Imbalances', SAIIA, Occasional Paper No.110, retrieved on 20 July 2012 from http://www.saiia.org.za/images/stories/pubs/ occasional_papers_above_100/saia_sop_\%20110_patroba_20120327.pdf. Primack, David. 2007/08. 'EPA fails to draw the Pacific closer to the international trading System', Trade Negotiation Insight, Vol. 6, No. 8, retrieved on 20 July 2012 from http://www.acp-eu-trade.org/index.php?loc=tni/.

Scollay, Robert. 2010. 'South-South and North-South trade agreements: the Pacific Island case', UNU-CRIS, working papers, W-2010/7, retrieved on 20 July 2012 from www.acp-eu-trade.org/.../Scollay EN 81210 UNUCRIS SouthSouth\%20and\%20North-South\%20Trade\%20Agreements.pdf.

Secretariat of the Pacific Regional Environment Program. 2009. 'Media release', 23rd March, retrieved on 20 July 2012 from http://www.sprep. org/ article/news_detail.asp?id=616.

Stewart, R. 2008. 'An Economic Survey of Developing Countries in the Pacific Region'. Department of Treasury, retrieved on 20 July 2012 from http:// www.treasury.gov.au/documents/1190/PDF/08 pacific.pdf.

Squires. Nick. 2005. 'Pacific Persuasion, Beijings Increasing Economic Muscles in the South Pacific' South China Morning Post. 21st July.

The Australian. 2007. 'China's neo-colonial slavery in PNG', 12nd February, retrieved on 04 September 2012 from http://www.theaustralian.com.au/ business/chinas-neo-colonial-slavery-in-png/story-e6frg8zx-1111112977807. 


\section{AFRICAN \\ EAST-ASIAN \\ AFFAIRS \\ THE CHINA MONITOR}

The Star. 2012. 'City hawkers protest Chinese infiltration, 17th August', retrieved on 04 September 2012 from http://www.the-star.co.ke/national/ national/90031-hawkers-demonstrate-against-chinese-infiltration.

Thierry, Ogier. 2011. 'Brazil 'provokes' partners with new South-South fund' retrieved on 20 July 2012 from http://www.emergingmarkets.org/ Article/2845792/Brazil-provokes-partners-with-new-South-South-fund.html.

Trade Negotiation Insight. 2007. 'EU, Pacific class over EPA funds', Vol. 6 No.

5, retrieved on 20 July 2012 from http://www.acp-eu-trade.org/index.php? $\underline{\text { loc }=\text { tni } / .}$

Tuiloma, Neroni Slade. 2012. 'Secretary General of the Pacific Islands Forum Secretariat remarks at the opening ceremony of the Forum's 43 meeting in Cook Island - 28 August' retrieved on 04 September 2012 from http:// www.forumsec.org/pages.cfm/newsroom/press-statements/2012/43rd-pacificislands-forum-opens-in-cook-islands.html.

UN Economic and Social Commission for Asia and the Pacific (UN-ESCAP). 2011. 'South-South Cooperation in Asia-Pacific: Emerging trends and potential', MPDD policy brief, No. 9, retrieved on 20 July 2012 from www.unescap.org/pdd/publications/me brief/mpdd-pb-9.pdf.

. 2004. 'Bulletin on Asia-Pacific Perspectives 2003/04' Chapter III, retrieved on 20 July 2012 from http://www.unescap.org/pdd/publications/bulletin03-04/ bulletin03-04_ch3.pdf.

UN Educational, Scientific and Cultural Organization (UNESCO). 2010. 'Water e-Newsletter' No. 228, retrieved on 20 July 2012 from http://www.unesco.org/ water/news/newsletter/228.shtml.

UN Food and Agriculture Organization (FAO). 2008. 'Climate Change and Food Security in Pacific Island Countries’, retrieved on 20 July 2012 from http://www.fao.org/docrep/011/i0530e/i0530e00.HTM. 
World Bank. 2000. 'Effects of Population Growth and Urbanization in the Pacific Islands', retrieved on 20 July 2011 from http:// siteresources.worldbank.org/INTPACIFICISLANDS/Resources/Chapter+1.pdf.

World Health Organization. 2008. 'Sanitation, Hygiene and Drinking-Water in the Pacific Island Countries: Converting Commitment into Action', retrieved on 20 July 2012 from http://www.wpro.who.int/NR/rdonlyres/719C55C7-3D2548F4-B3A9- CFEBB998BA90/0/PacificReport_Finall copy6.pdf.

Wrights, Chris. 2011. 'Pacific nations outline sovereign wealth plans', retrieved on 20 July 2012 from http://www.emergingmarkets.org/Article/2818285/News/ Pacific-nations-outline-sovereign-wealth-plans.html.

Xinhua News. 2012. 'China-NZ joint Pacific aid project targets water in Cook Islands', 31st August, retrieved on 14 September 2012 from http:// www.chinadaily.com.cn/xinhua/2012-08-31/content 6879657.html. 


\begin{tabular}{|} 
AFRICAN \\
EAST-ASIAN \\
AFFAIRS \\
\hline THE CHINA MONITOR \\
\hline
\end{tabular}

\section{Annex 1: Total net ODI (US\$ millions)}

\begin{tabular}{|c|c|c|c|c|c|c|c|c|c|c|c|c|c|c|c|}
\hline & \multicolumn{3}{|c|}{ Asureatis } & \multicolumn{3}{|l|}{ Tapse日 } & \multicolumn{3}{|c|}{ Sere Znowased } & \multicolumn{3}{|l|}{$\mathrm{CAS}$} & \multicolumn{3}{|c|}{ 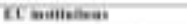 } \\
\hline & $200 \%$ & hen & 2000 & 2604 & 2307 & DIOA & Lint & 2167 & Daw & Wett & 2004 & 2000 & Dout & Jien: & J60 \\
\hline Caskíason & Iaf & $2 \%$ & Tor & o.16 & DI & 609 & 260 & 986 & In & b & 6 & 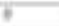 & 6 & asy & 63 \\
\hline$r w$ & 2046 & 16.1 & 2001 & 2.59 & S.M & 2.11 & Wh & $1, A 4$ & wio & 0,6 & 131 & 1,04 & 60.7 & $96+2$ & wn \\
\hline Kintesil & $7 \mathrm{II}^{2}$ & 394 & 160 & TIEN & Das & $6 \% 4$ & TES & J.4 & 503 & 608 & $0 \%$ & 6.60 & W & 3.86 & 19 \\
\hline Monhatiageds & 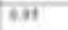 & 065 & 16 & 1626 & 2.11 & 3 & 0.13 & 0.99 & 0 & $4+4$ & 61.1 & $10(9)$ & $\theta$ & 1,01 & 17 \\
\hline 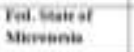 & i,, 4 & tas & 2.11 & 0.04 & 9.5 & 4s, & 6.34 & 0.67 & 0.1 & $\mathrm{mas}$ & wos & 10454 & 0 & 0.46 & $1.4 t$ \\
\hline Nokm & $7,2 \kappa^{2}$ & Fin & in: & C.d & $13 \pi$ & $24 !$ & Eम & Dx & III & (1) & (1) & 8 & 百 & 0.24 & $m$ \\
\hline $\operatorname{sen}$ & 7.16 & 8.9 & 3.34 & 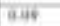 & 0 a) & wit & TSM & 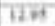 & 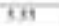 & ii: & 0 & 8 & 6. & 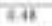 & 9.34 \\
\hline Palae & $60 \%$ & $a \pi$ & $T=1$ & कW & 805 & Balt & $20 \mathrm{~m}$ & (7)i & ini & III & 10.1 & $26 \%$ & 6 & 839 & कas \\
\hline PSE, & 2397 & $m \pi$ & 300 & का & 79.83 & 416 & 65 & Trys & $14: 5$ & ias & ate & 246 & 12.86 & 3.18 & 3130 \\
\hline seases & $120 t$ & 13 & $1+\pi$ & 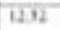 & 64 & inat & 1.20 & 625 & 1034 & क्ष & 102 & 1.4 & 37 & 60.12 & o.nt \\
\hline Babese filonat & 1302 & 201.00 & ina.7" & 14.16 & 14.4 & s.9s & ins & 19,96 & 243 & 0.62 & 831 & 2.6 & ม." & 3.4 & 3.94 \\
\hline fakitas & 6.2. & a.t. & an: & a & 6 & d & $10 \mathrm{n}$ & I2 & In & 8: & 5 & 7 & 6 & 8 & $\theta$ \\
\hline teasen & 6.6 & Tan & Wa & 024 & 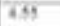 & $m, y$ & 73 & Trm & $7 x$ & $696^{\circ}$ & $6+9$ & 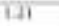 & $2 \mathrm{H}$ & कIF & क.96 \\
\hline fursai & मn & 8.54 & 76 & 1 年 & 294 & 35 & 763 & 78 & T.M & 5 & $\overline{5}$ & 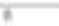 & 29 & ia & ज्या \\
\hline V.teasta & 1960 & $22 \pi$ & 6006 & $\omega$ & (a) & Dat: & ige & 9. & 159 & 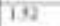 & $7 x$ & Ware & 36 & A.) & Tye \\
\hline Tatal & $4612 \pi$ & $m+2 n$ & 600.24 & कeता & at:9 & ist. 40 & mian & 96.51 & 105.01 & $3 \in \%$ & 100.94 & ISEAT & चलत & Ai. & 28.9 \\
\hline
\end{tabular}

Source: Organisation for Economic Co-operation and Development (OECD), http://www.oecd.org/statistics/

\section{Annex 2. The Pacific Islands}

Spread across a vast expanse of ocean, Pacific Island peoples occupy an array of environments, from Papua New Guinea (PNG)'s massive mountains to the atolls and lagoons of European fantasy to Auckland New Zealand's urban jungles. Equally, the region is home to large natural resource (fish, timber, agricultural produce, oil, gas and minerals. Its major efforts are to mitigate climate change given its rich biodiversity ${ }^{16}$.

The Pacific Islands are grouped into three sub-regions of Polynesia (southeast ${ }^{17}$ ), Micronesia (north ${ }^{18}$ ) and Melanesia (west ${ }^{19}$ ), based on their ethnic, 
linguistic and cultural differences. Spread over 30 million sq $\mathrm{km}$, more than $98 \%$ of which consists of ocean, the islands feature great geographical diversity. Melanesian islands are large mountainous and volcanic (with rich soils, mineral deposits and plentiful marine resources), while the Polynesian and Micronesian islands are smaller with fewer resources.

The Island states have been keen to encourage development of offshore fishing activities, to generate income and to reduce pressure on inshore resources. Most of these countries with the exception of Fiji, PNG and the Solomon islands have limited natural and human resources to stimulate sustainable development.

\section{Annex 3: Country profile.}

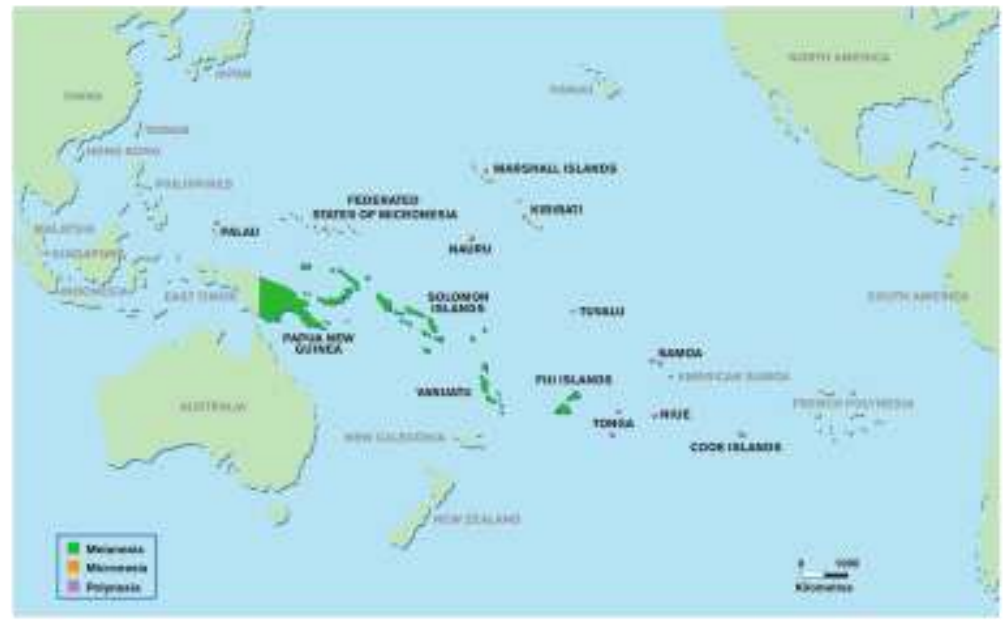

Source: Google maps, https://maps.google.co.ke/maps?

$\underline{h l=s w \& q=\text { pacific }+ \text { islands } \& i e=U T F-8}$ 